\title{
Peertechz
}

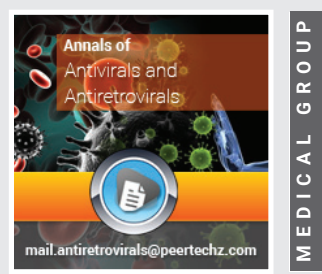

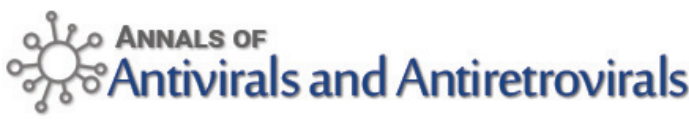

\section{Corona virus affects fertility: A}

\section{concern}

\section{Dharmendra Kumar*, Rishabha Malviya and Pramod Kumar Sharma}

Department of Pharmacy, School of Medical and Allied sciences, Galgotias University, Gautam Buddha Nagar, Uttar Pradesh, India
Received: 03 April, 2019

Accepted: 25 April, 2020

Published: 27 April, 2020

*Corresponding author: Dharmendra Kumar, Department of Pharmacy, School of Medical and Allied sciences, Galgotias University, Plot No. 2, Sector 17-A, Yamuna Expressway, Greater Noida, Gautam Buddha Nagar, Uttar Pradesh, India, Tel: +91-8512009949; E-mail: rvnimiet@gmail.com

Keywords: CORONAVIRUS; Fertility; CoVID19; SARSCoV19

https://www.peertechzpublications.com

Check for updates

\section{Abstract}

Nowadays, world suffer from the outbreak of CORONAVIRUS pandemic. New Case of corona infection increases daily. No satisfied treatment or vaccine is available. Another a new concern is thriving in community is that CORONAVIRUS will affect their fertility.

CORONAVIRUS is spherical or pleomorphic, single stranded, enveloped RNA and covered with club shaped glycoprotein. CORONAVIRUSES are four sub types such as alpha, beta, gamma and delta CORONAVIRUS. First case of CORONAVIRUS was notified as cold in 1960. According to the Canadian study 2001, approximately 500 patients were identified as Flu-like system. COVID-19 was first identified and isolated from pneumonia patent belongs to Wuhan, china [1]. Now it is announced as pandemic by WHO. More than 10 lacks corona case and fifth thousands of deaths are confirmed worldwide [2]. Infertility is "a disease of the reproductive system defined by the failure to achieve a clinical pregnancy after 12 months or more of regular unprotected sexual intercourse [3]. Infertility affects an estimated one sixth of couples's worldwide amounting 50 millions couple. Male are found more responsible for $20-30 \%$ of infertility cases of contributed around $50 \%$ of overall cases. CORONAVIRUS added another factors for infertility [4]. The cause of infertility may difficult to determine but may includes many inadequate level of sex hormone in both women and man or problem with ovulation in women. Problem with the production and maturation of sperm are common causes of man fertility. Immature or abnormal sperm (terotospermia), unable to move properly (asthenospermia), low sperm count (oligospermia) and seemingly not at all (azoospermia) may common causes in mens due to different condition and infections. CORONAVIRUS may one of them [5]. According to male fertility expert Prof. Allan Pacey from University of Sheffield U.K., CORONAVIRUS possibly impact on male fertility.
He has emphasized in a discussion that CoVID-19 will definitely affect the male fertility. While an another expert in fertility from MRC centre for reproduction health, University of Edinbargh U.K., report that CORONAVIRUS affect the human fertility but no direct evidence was recorded by scientist till. Many doctors from china advised and urged that CORONAVIRUS patient must test their fertility as soon as possible because doctors feel that CORONAVIRUS may damage the function of testicles. While no study has proved that CORONAVIRUS reduce sexual potency and mans fertility. But many researchers also suggested that CORONAVIRUS infection may affect the production of sperm and formation of male sex hormone [6]. According to the Prof. Li Yufeng from centre for reproduction medicine china, CORONAVIRUS mainly targets lungs and immune system of patient so there is a possibility to impair a men's ability to reproduce or production of sperm count. He also added that CORONAVIRUS enters in human cells and causes tissue damage by binding spike protein via angiotensin-converting enzyme-2. Angiotensin-converting enzyme-2 is present in lungs and abundant in men's testes. It can be concentrated in many cells related to male reproduction ability including germ cells, supporting cells and leydig cells. He also added the theory of SARS outbreak in 2002-03 that medics observed the serious immune system damage in testicles of many male patients. Many patients of SARS were found with inflammation in their sexual organ. While CoVID-19 is much similar to SARS so possibility of infertility in man increased [7]. CORONAVIRUS infected patient have various common symptoms like 
pneumonia, dry cough, sneezing, and fever. Doctors advised do not take medicine (such as ibuprofen, aspirin) without doctor's consultation. These make difficulty to conceive. Those patient get depression and psychosis, don't take neuroleptic medicine himself. These can cause missed period or infertility [8]. Depression and stress in peoples due to CORONAVIRUS was observed by doctors. So it is clear that human infertility may not affected by CORONAVIRUS but it will reduced due to depression and stress of patient due to treatment or isolation of corona infected patient. Finally author advised that peoples should not hesitate to consult with their doctor if they feel any problem with their fertility or symptoms.

\section{References}

1. Kumar D, Malviya R, Kumar Sharma P (2020) CORONAVIRUS: A Review of COVID-19. EJMO 4: 8-25. Link: https://bit.ly/3aDWX8S
2. Link: https://bit.ly/2Kv6kNG

3. Link: https://bit.ly/3eQM2MA

4. Agarwal A, Mulgund A, Hamada A, Chyatte MR (2015) A unique view on male infertility around the globe. Reprod Biol Endocrinol 13: 37. Link: https://bit.ly/2Y37Nmh

5. Link: https://shc.is/354ZFmG

6. Link: https://bit.ly/2xMrdBn

7. Doctors claim new coronavirus 'may cause damage to a man's TESTICLES' as they urge male patients to take fertility tests upon recovery. Link: http://dailym.ai/3aDFei7

8. Link: https://bit.ly/2KzGSXa
Discover a bigger Impact and Visibility of your article publication with

\section{Peertechz Publications}

\section{Highlights}

* Signatory publisher of ORCID

* Signatory Publisher of DORA (San Francisco Declaration on Research Assessment)

* Articles archived in worlds' renowned service providers such as Portico, CNKI, AGRIS, TDNet, Base (Bielefeld University Library), CrossRef, Scilit, J-Gate etc.

* Journals indexed in ICMJE, SHERPA/ROMEO, Google Scholar etc.

* OAI-PMH (Open Archives Initiative Protocol for Metadata Harvesting)

* Dedicated Editorial Board for every journal

* Accurate and rapid peer-review process

* Increased citations of published articles through promotions

- Reduced timeline for article publication

Submit your articles and experience a new surge in publication services (https://www.peertechz.com/submission).

Peertechz journals wishes everlasting success in your every endeavours.

Copyright: @ 2020 Kumar D, et al. This is an open-access article distributed under the terms of the Creative Commons Attribution License, which permits unrestricted use distribution, and reproduction in any medium, provided the original author and source are credited. 